\title{
Mantle source characterization of Sylhet Traps, northeastern India: A petrological and geochemical study
}

\author{
Md Shofiqul Islam ${ }^{1,2, *}$, Daniel Meshesha ${ }^{1,3}$ and Ryuichi Shinjo ${ }^{1}$ \\ ${ }^{1}$ Department of Physics and Earth Sciences, University of the Ryukyus, Senbaru 1, Nishihara, \\ Okinawa 903-0213, Japan. \\ ${ }^{2}$ Department of Petroleum and Mining Engineering, Shahjalal University of Science and Technology, \\ Sylhet 3114, Bangladesh. \\ ${ }^{3}$ EL MINING PLC, Addis Ababa, Ethiopia. \\ *Corresponding author. e-mail: sho_fiq@yahoo.com
}

In this study, mineralogical, geochemical, and isotopic data are presented for the Sylhet Trap at the southern flank of the eastern Shillong Plateau, northeastern India, to determine the magma genesis in relation to the Kerguelen plume mantle source. Sylhet Trap rocks are porphyritic tholeiite and have diverse chemical compositions from picro-basalt, basalt, andesite to dacite, but mostly are within the subalkaline field. Major and trace element data were used to identify two distinct magma fractionation trends, a low and medium $\mathrm{K}$ series, characterized by relatively flat MORB-like (analogous to Rajmahal Traps (II)) and enriched OIB chondrite-normalized Rare Earth Element (REE) patterns. Initial ${ }^{87} \mathrm{Sr} /{ }^{86} \mathrm{Sr}$, ${ }^{143} \mathrm{Nd} /{ }^{144} \mathrm{Nd}$, and ${ }^{206} \mathrm{~Pb} /{ }^{204} \mathrm{~Pb}$ isotope compositions were widely varied, ranging from $0.70435-0.71357$, 0.51196-0.51266, and 17.92-19.72, respectively, when compared with basalts from the West Bengal, the Rajmahal Traps and the Kerguelen plume. Correlations among isotopic and trace element ratios of the Sylhet Traps provide evidence for the involvement of (1) HIMU-like mantle component, (2) the Kerguelen plume-like component, and (3) EMII-like crustal component. Magma from the Sylhet Traps was originated from a melting that derived directly from the heterogeneous Kerguelen mantle plume (components 1 and 2), which strongly suggests the presence of the Kerguelen plume-head in the Bengal basin.

\section{Introduction}

The volcanic outpouring of the southern Indian Ocean covers an enormous region consisting of the Kerguelen Plateau, the Broken Ridge, the Bunbury (southwestern Australia), and northeastern India (Rajmahal-Sylhet traps). This area's original formation derived from the breakup of the Indian and the Australian plate and is usually thought to be associated with the Kerguelen hotspot-mantle plume system that occurred ca. 132 Ma (Kent et al. 1997, 2002; Frey et al. 2000a, b; Coffin et al.
2002; Ray et al. 2005; Srivastava and Sinha 2007). Moreover, Srivastava and Sinha (2007) proposed that the Kerguelen hotspot was located near the eastern Indian margin between 100 and $120 \mathrm{Ma}$ and was responsible for the Rajmahal basalts that are exposed over the Gondwana Supergroup and the Sylhet Traps rocks of the Shillong Plateau.

The Shillong Plateau is part of northeastern India (figure 1) and is characterized by Proterozoic ultramafic (Rao et al. 2009) to Late Cretaceous ultramafic-mafic alkaline magmatic activity (e.g., Srivastava and Sinha 2004; Saha

Keywords. Sylhet Traps; Shillong Plateau; Kerguelen; mantle plume. 


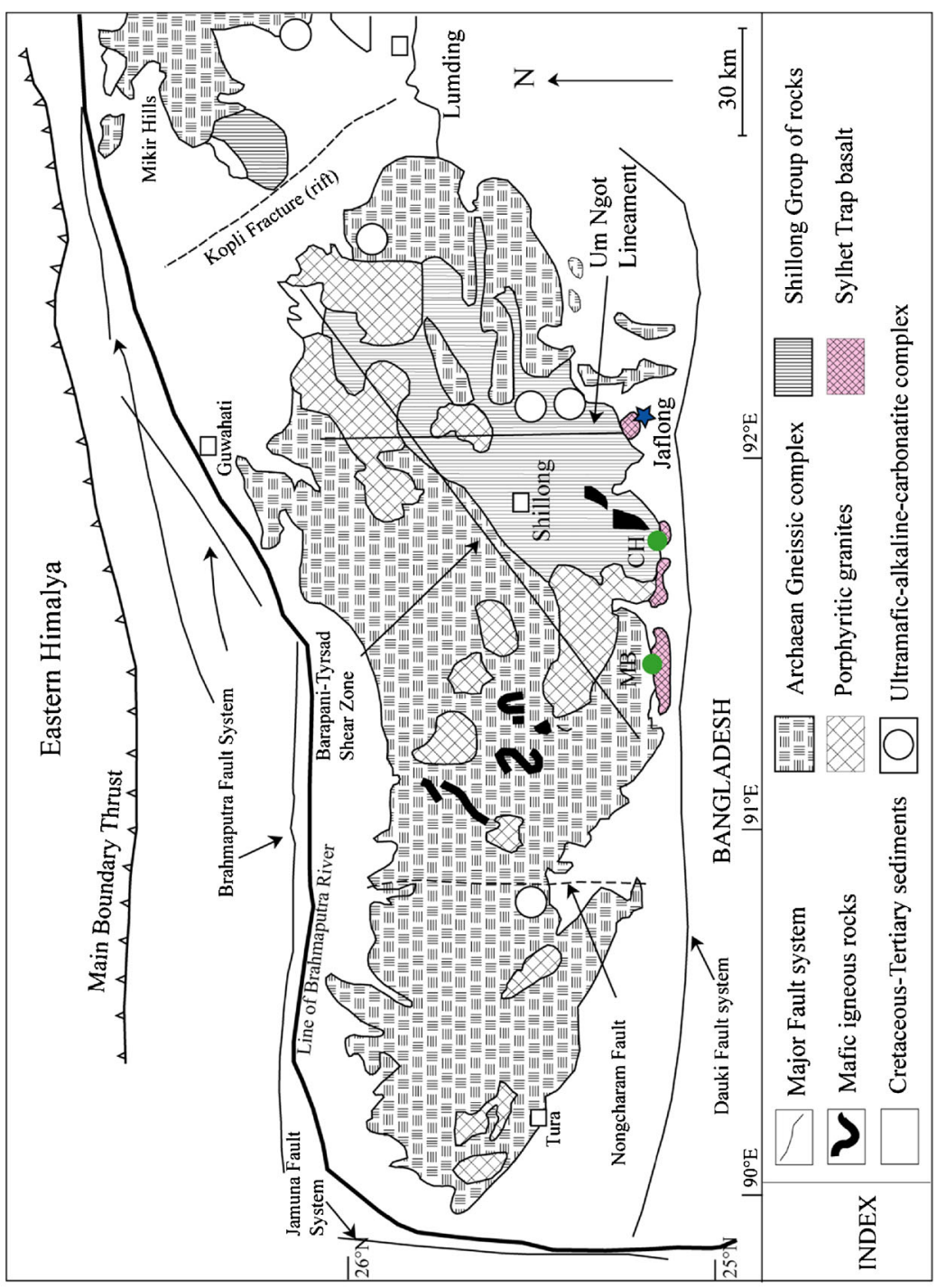

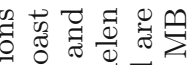

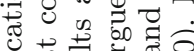

o

60 .

等

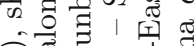

6

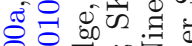

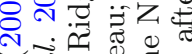

वें

๑

ه.d记

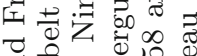

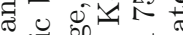

สิ

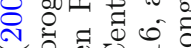

उ

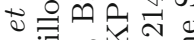

0 覀

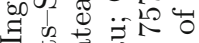

-

구 $a$

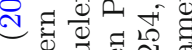

कै 300

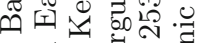

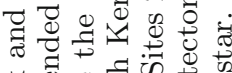

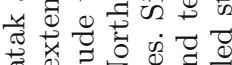

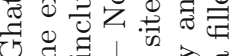

年

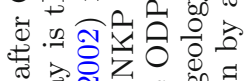

ज.

.

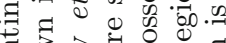

훙

(2)

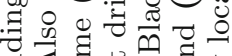

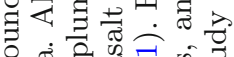

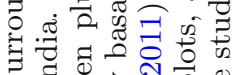

क

สี

I

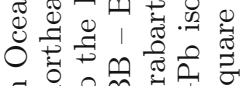

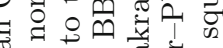

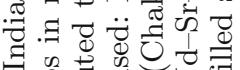

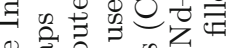

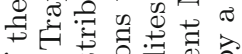

प兀

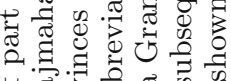

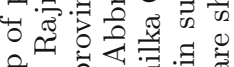

बैच

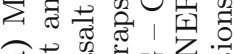

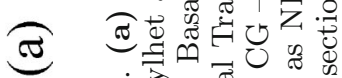

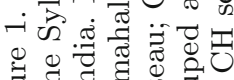

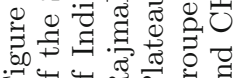


et al. 2010). Many previous studies (e.g., Storey et al. 1992; Kent et al. 1997, 2002; Ray et al. 1999; Srivastava and Sinha 2004, 2007) have suggested that the spatial and temporal distribution of Shillong Plateau magmatism are related to a plume that is presently beneath Kerguelen. It has also been suggested that the nature of the Shillong Plateau volcanism is plume-related N-MORB (Rao et al. 2009) or OIB (Veena et al. 1998; Srivastava and Sinha 2007). A recent geochemical and $\mathrm{Nd}-$ $\mathrm{Sr}-\mathrm{Pb}$ isotopic study on the Sylhet Traps (STGB) from the Cherrapunji-Shella bazaar $(\mathrm{CH})$ and Mawsynram-Balot (MB) sections in the Shillong Plateau (Ghatak and Basu 2011) suggested that the Sylhet Traps basalt of the CH section is associated with E-MORB; whereas, basalts from the MB section involve lower crustal contamination. Rare earth elements (REEs) in the Sylhet Trap basalts are characterized by high La abundance and experience less contamination, similar to the Rajmahal basalt (Storey et al. 1992; Kent et al. 1997) and the ODP sites on the Karguelen Plateau (Weis et al. 2001; Ingle et al. 2002; Kurnosov et al. 2003).

However, since a report on the Sylhet Trap basalts by Palmer (1923), and subsequent geologic, petrochemistry and tectonic studies (Talukdar 1966; Talukdar and Murthy 1971) were performed, there has been limited research in this area. Recently, Ghatak and Basu (2011, 2013) reported on the heterogeneity of the Kerguelen Plateau of tholeiitic series (with high $\mathrm{Mg} \#$ of $\sim 60-61$ ) from the Shillong Plateau, and there have been a few dyke samples taken from Bihar-West Bengal. Therefore, there is a need to perform additional detailed studies on the petrography, geochemistry, and isotopic characteristics of other sections in the region to fully understand the origin and nature of the Sylhet Trap basalts. In this study, we present petrographic, geochemical, mineralogical, isotopic data for samples collected in the eastern portion of the Shillong Plateau, including a $\mathrm{K}$-Ar dating result from one relatively primitive basalt. Our dataset will be used to discuss: (i) the temperature-pressure conditions for mineral accumulation of the Sylhet Traps, and (ii) the nature of the mantle source with respect to the Kerguelen plume.

\section{Geology of the area}

The Shillong Plateau has a 'pop-up' structure between the Brahmaputra Valley in the north and the Surma Valley in the south. The Shillong Plateau is dissected by major E-W, N-S, and NWSE oriented faults (Nongchram Fault, Um Ngot lineaments, Barapani-Tyrsad shear zone, Chedrang Fault, Dudhnoi Fault, Kopili lineaments) related to tectonic forces from both the Himalayan collision zone and the Indo-Burma subduction zone (Kayal 2001; Islam et al. 2011). This type of plateau is usually observed in a convergent tectonic setting with major plateau bounding strike-slip faults (Schellart and Nieuwlan 2003; Islam et al. 2011). Although substantial research has been performed in this area, there remain debates about the Shillong Plateau bounding faults, its origin and major earthquake producing deformation (Oldham 1899; Evan 1964; Verma and Mukhopadhyay 1977; Hiller and Elahi 1984; Chen and Molnar 1990; Johnson and Alam 1991; Bilham and England 2001; Rajendran et al. 2004; Mitra et al. 2005; Srinivasan 2005; Rajasekhar and Mishra 2008; Islam et al. 2011). The Sylhet Trap (figure 1) is exposed in a narrow east-west strip, 60-80 km long and $4 \mathrm{~km}$ wide (Talukdar and Murthy 1971; Saha et al. 2010) along the southern edge of the Shillong Plateau with maximum thickness of $\sim 500-650 \mathrm{~m}$ (Mazumder 1986; Baksi et al. 1987). It is a part of the Sylhet-Rajmahal flood basalt province at the southern margin of the Shillong Plateau at $\sim 117$ 115 Ma (Ray and Pande 2001) and is associated with the Kerguelen mantle plume activity (Storey et al. 1992; Kent et al. 1997, 2002; Srivastava and Sinha 2004). The Traps appear to overlie the eroded Pre-Cambrian basement and are inconsistently overlain by Upper Cretaceous-Eocene sediments (figure 1b). The sediments and the lavas outline a monocline that becomes a flexure southward, and the sediments at the top of the flexure have subsequently been eroded in places (Biswas and Grasemann 2005; Islam et al. 2010). This flood basaltic volcanism is generally associated with the breakup of the Gondwana supercontinent and the northward movement of the Indian plate and its ultimate collision with the Eurasian plate (Rao 2002). However, Talukdar and Murthy (1971) suggested that the Sylhet Traps were not extruded outside the present northern limit of the Raibah Fault and the southern limit of the Dauki Fault. For example, the Dauki was initiated and sustained activity through the Tertiary to Recent times. There is no evidence supporting volcanism with an association of vertical movement on the Dauki Fault. However, Talukdar and Murthy (1971) also proposed that the Dauki Fault may be another zone of fissure where eruptions may have occurred. Gupta and Sen (1988) observed, using Landsat images and aerial photographs that a N-S trending Um Ngot lineament cuts across the general NE-SW trend of the Shillong Plateau (figure 1b). This lineament developed during the late JurassicEarly Cretaceous period and contains several alkaline intrusive bodies, including the Sung Valley complex (ultramafic-alkaline-carbonatite complex) and is geologically related to the Ninety-East 
Ridge in the Indian Ocean (Gupta and Sen 1988; Srivastava and Sinha 2004; Srivastava et al. 2005). Several granite plutons (700-450 Ma) also intrude the gneissic basement and the Shillong Group envelops sequence. The Archaean gneissic basement of the Shillong Plateau is traversed by a number of mafic dyke swarms (Rao et al. 2009). Two suites of dykes have been reported by Rao et al. (2009) in the Garo Hills that represent Proterozoic Khasi greenstone related dolerites and younger Cretaceous dolerite dykes. In places, bodies of metamorphosed mafic igneous rocks have also been reported (Mazumder 1976; Ghosh et al. 1994).

\section{Petrography}

The Sylhet Traps are predominantly comprised of basalts. The Sylhet Traps volcanic rocks are predominantly porphyritic (figure 2 ), containing $\sim 4 \%$ to $19 \%$ phenocrysts. The major phenocrysts phases are plagioclase and pyroxene, but only sample 7 contains $16 \%$ olivine. Sample 1 is highly weathered, with phenocrysts of orthopyroxene, quartz, albite, and calcite (all these minerals are alteration products). In this sample, groundmasses are comprised of albite, ilmenite, orthopyroxene, and biotite. Sample 4 is dacite with a predominant phenocryst of amphibole; whereas, the minor phenocrysts consist of albite, ilmenite, and magnetite. Samples 5 and 6 are composed of similar types of phenocrysts and groundmasses. The phenocrysts are plagioclase (labradorite, andesine) and clinopyroxene (augite) and the groundmasses consist of plagioclase (labradorite, andesine), clinopyroxene (augite, pigeonite), and ilmenite. The olivine-rich $(>16 \%$ ) sample (sample 7 ) is predominantly composed of olivine (forsterite) with some clinopyroxene (augite) as phenocrysts. Spinel inclusions were identified within a few olivine phenocrysts. In the groundmasses, olivine (forsterite), plagioclase (albite, labradorite), ulvospinel, and ilmenite were found. Sample 10 contains phenocrysts of plagioclase (bytonite) and clinopyroxene (augite) within a groundmass of clinopyroxene (augite), plagioclase (andesine, labradorite), and ilmenite.

\section{4. $\mathrm{K}$-Ar dating}

Sample 7 is a very distinct sample that contains fresh olivine phenocrysts and similar samples have never been reported in previous studies. Therefore, to place constraints on volcanic activity, we conducted $\mathrm{K}-\mathrm{Ar}$ dating on this sample, which revealed an age of $84.0 \pm 1.9 \mathrm{Ma}$ (table 1). Groundmass separates (mesh size, \#100-200), concentrated by means of magnetic separation, were analyzed for K and Ar at the Okayam University of Science, Japan and the calculation of age and errors were determined using the methods described by Nagao et al. (1984) and Itaya et al. (1991). Decay constants for ${ }^{40} \mathrm{Ar}$ and ${ }^{40} \mathrm{Ca}$ and the ${ }^{40} \mathrm{~K}$ content in potassium used in the age calculation are derived from Steiger and Jäger (1977): $0.581 \times 10^{-10} / \mathrm{y}, 4.962 \times 10^{-10} / \mathrm{y}$ and $1.167 \times 10^{-4}$, respectively. Our $\mathrm{K}-\mathrm{Ar}$ dating results, along with previous studies (Ray et al. 2005), indicate that plume-related Sylhet basalt emplaced during 120-84 Ma, which is similar to the $\sim 118-84$ Ma age of the Rajmahal Traps (Baksi et al. 1987). These data contrast with the ${ }^{40} \mathrm{Ar}-{ }^{39} \mathrm{Ar}$ dating results of $118-105 \mathrm{Ma}$ for basalts from the Rajmahal-Bengal-Sylhet Traps (Cherrapunji-Shella bazaar section) (Baksi 1995; Coffin et al. 2002; Kent et al. 2002).

\section{Analytical methods}

Six volcanic rock samples were collected from the Dauki river bed at the Jaflong point $\left(25.11^{\circ} \mathrm{N}\right.$, $92.01^{\circ} \mathrm{E}$ ) of Sylhet. Mineral chemical analyses were conducted using energy-dispersive X-ray spectroscopy (EDX; EDAX ${ }^{\mathrm{TM}}$ Genesis 4000) attached to a scanning electron microscope (SEM; Hitachi $300 \mathrm{~N}$ ) at the Department of Physics and Earth Sciences, University of the Ryukyus. The SEMEDX operating conditions were $20 \mathrm{kV}$ and $0.5 \mathrm{nA}$. The whole-rock major and selected trace elements (Ba, Co, Nb, Ni, Rb, Sr, V, Y, and Zr) were determined (table 2) on fused glass beads by X-ray fluorescence spectrometry (Shimadzu XRF-1800) at the Department of Physics and Earth Sciences, University of the Ryukyus. Reproducibility and accuracy of the XRF analyses were verified using international rock standards (JA-1 and BHVO-2).

Additional whole-rock trace element concentrations (including rare earth elements (REE)) were analyzed by inductively coupled plasma mass spectrometry (ICP-MS; Yokogawa Analytical System (now Agilent Technologies) HP 4500) at the University of the Ryukyus (table 3). The detailed analytical procedure is described in Shinjo et al. (2000). The precision and reproducibility of the ICP-MS measurements were verified using international rock standards: BIR-1, JA-1, JP-1, JB-1, JB-2, and DST-2. The accuracy of the majority of trace element analyses was $\pm 5 \%$ relative to the recommended values.

$\mathrm{Sr}, \mathrm{Nd}$, and $\mathrm{Pb}$ isotope analyses were performed on a Finnigan MAT262 mass spectrometer at the University of the Ryukyus, using the procedures outlined in Shinjo et al. (2000) and Wang et al. (2004) (table 4). The isotopic ratios were corrected for mass fractionation by normalizing to ${ }^{86} \mathrm{Sr} /{ }^{88} \mathrm{Sr}=0.1194$ and ${ }^{146} \mathrm{Nd} /{ }^{144} \mathrm{Nd}=0.7219$. In this 

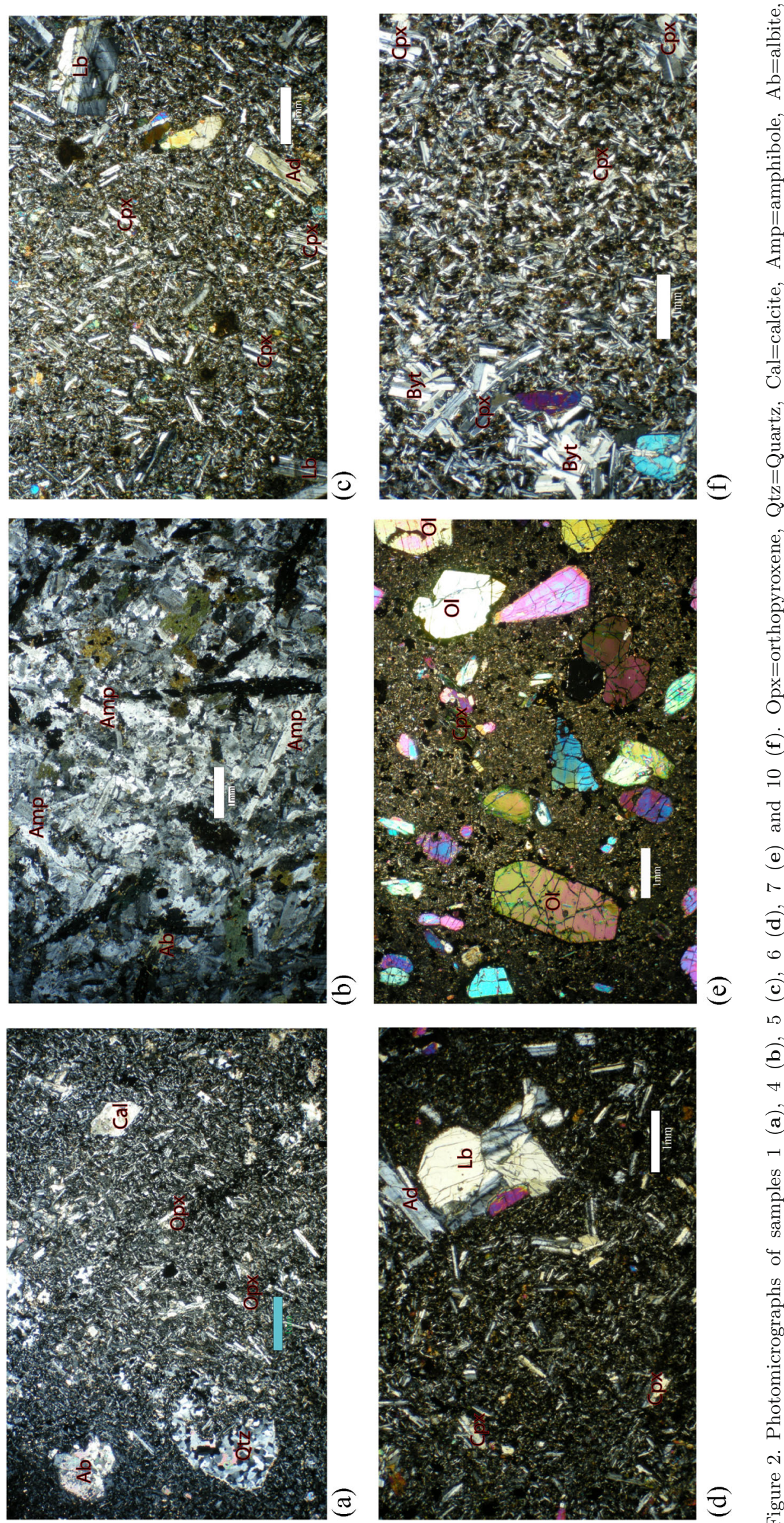

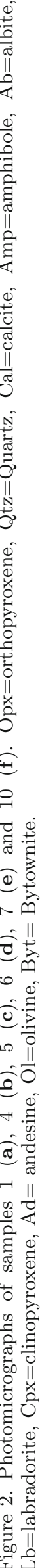


Table 1. K-Ar dating result of sample $\%$.

\begin{tabular}{lcccccc}
\hline Sample no. & $\begin{array}{c}\text { Specimen type } \\
(\text { mesh size })\end{array}$ & $\begin{array}{c}\text { K content } \\
(\text { wt } \%)\end{array}$ & $\begin{array}{c}\text { radiogenic }{ }^{40} \mathrm{Ar} \\
\left(10^{-8} \text { cc STP/g) }\right.\end{array}$ & $\begin{array}{c}\mathrm{K}-\mathrm{Ar} \\
\text { age }(\mathrm{Ma})\end{array}$ & $\begin{array}{c}\text { Nonradiogenic } \\
40\end{array}$ & $\begin{array}{c}\text { Reproducibility } \\
(\%)\end{array}$ \\
\hline BGD-7 & $\begin{array}{c}\text { Concentrated groundmass } \\
(\# 100-200)\end{array}$ & $0.684 \pm 0.014$ & $228.2 \pm 2.5$ & $84.0 \pm 1.9$ & 12.3 & 0.28 \\
\hline
\end{tabular}

Table 2. Major element compositions.

\begin{tabular}{|c|c|c|c|c|c|c|}
\hline Sample & 1 & 4 & 5 & 6 & 7 & 10 \\
\hline $\mathrm{SiO}_{2}(\mathrm{wt} \%)$ & 47.77 & 64.81 & 52.04 & 50.58 & 44.53 & 49.83 \\
\hline $\mathrm{TiO}_{2}$ & 2.00 & 1.09 & 1.998 & 1.98 & 2.02 & 2.85 \\
\hline $\mathrm{Al}_{2} \mathrm{O}_{3}$ & 15.27 & 12.41 & 13.43 & 13.46 & 8.17 & 14.61 \\
\hline $\mathrm{Fe}_{2} \mathrm{O}_{3}^{\mathrm{T}}$ & 12.74 & 11.59 & 12.69 & 12.88 & 12.44 & 12.21 \\
\hline $\mathrm{MnO}$ & 0.19 & 0.17 & 0.288 & 0.27 & 0.19 & 0.16 \\
\hline $\mathrm{MgO}$ & 6.47 & 0.46 & 5.44 & 5.73 & 12.29 & 4.04 \\
\hline $\mathrm{CaO}$ & 6.10 & 3.16 & 10.11 & 10.07 & 14.42 & 8.41 \\
\hline $\mathrm{Na}_{2} \mathrm{O}$ & 3.82 & 5.13 & 2.48 & 2.29 & 1.97 & 2.82 \\
\hline $\mathrm{K}_{2} \mathrm{O}$ & 0.38 & 0.80 & 0.49 & 0.43 & 0.80 & 1.55 \\
\hline $\mathrm{P}_{2} \mathrm{O}_{5}$ & 0.17 & 0.18 & 0.21 & 0.20 & 0.32 & 0.29 \\
\hline Total & 94.91 & 99.81 & 99.18 & 97.90 & 97.15 & 96.78 \\
\hline \multicolumn{7}{|c|}{ Trace element } \\
\hline $\mathrm{Ba}(\mathrm{ppm})$ & 139 & 422 & 140 & 129 & 331 & 462 \\
\hline $\mathrm{Co}$ & 50 & 10 & 42 & 44 & 64 & 41 \\
\hline $\mathrm{Cr}$ & 242 & 5 & 124 & 134 & 728 & 24 \\
\hline $\mathrm{Nb}$ & 11.8 & 23.7 & 11.7 & 11.2 & 28.3 & 26.1 \\
\hline $\mathrm{Ni}$ & 60 & 3 & 50 & 52 & 402 & 29 \\
\hline $\mathrm{Rb}$ & 13.7 & 20.3 & 9 & 7.3 & 28.9 & 36 \\
\hline $\mathrm{Sr}$ & 335 & 209 & 199 & 196 & 620 & 552 \\
\hline $\mathrm{V}$ & 309 & 1 & 308 & 300 & 291 & 330 \\
\hline $\mathrm{Y}$ & 31.4 & 92.7 & 34 & 31.4 & 19.6 & 27.7 \\
\hline $\mathrm{Zr}$ & 150 & 416 & 141 & 137 & 132 & 243 \\
\hline \multicolumn{7}{|l|}{ CIPW norm } \\
\hline $\mathrm{Q}$ & - & 24.25 & 8.48 & 7.57 & - & 5.88 \\
\hline Or & 2.388 & 4.77 & 2.94 & 2.62 & 4.91 & 9.54 \\
\hline $\mathrm{Ab}$ & 34.36 & 43.78 & 21.34 & 19.97 & 6.51 & 24.86 \\
\hline An & 24.87 & 8.54 & 24.48 & 25.96 & 11.52 & 23.58 \\
\hline $\mathrm{Ne}$ & - & - & - & - & 5.85 & - \\
\hline Di & 4.95 & 5.28 & 20.46 & 19.67 & 48.36 & 14.51 \\
\hline Hy & 21.58 & 3.32 & 11.78 & 13.72 & - & 8.81 \\
\hline $\mathrm{Ol}$ & 0.74 & - & - & - & 12.55 & - \\
\hline Mt & 6.66 & 7.57 & 6.18 & 6.14 & 5.54 & 6.47 \\
\hline Il & 4.04 & 2.08 & 3.86 & 3.89 & 3.99 & 5.64 \\
\hline Ap & 0.42 & 0.41 & 0.49 & 0.48 & 0.78 & 0.70 \\
\hline $\mathrm{Mg} \#$ & 60.35 & 12.44 & 55.91 & 56.41 & 73.53 & 50.25 \\
\hline
\end{tabular}

study, the NIST SRM-987 Sr standard had a mean of ${ }^{87} \mathrm{Sr} /{ }^{86} \mathrm{Sr}=0.710251 \pm 42(2 \mathrm{SD}, n=5)$ and the La Jolla $\mathrm{Nd}$ standard had a mean of ${ }^{143} \mathrm{Nd} /{ }^{144} \mathrm{Nd}=$ $0.511824 \pm 10$ (2SD, $n=2$ ). All data for the samples were normalized to a value of SRM- $987{ }^{87} \mathrm{Sr} /{ }^{86} \mathrm{Sr}=$ 0.71025 and La Jolla ${ }^{143} \mathrm{Nd} /{ }^{144} \mathrm{Nd}=0.51186$.
The ${ }^{207} \mathrm{~Pb}-{ }^{204} \mathrm{~Pb}$ double spike method was applied to the $\mathrm{Pb}$ isotope analyses. The compositions of fractionation-corrected values of the NIST SRM-981 Pb standard $(n=2)$ during this study have ${ }^{206} \mathrm{~Pb} /{ }^{204} \mathrm{~Pb}=16.939 \quad( \pm 6 ; \quad 2 \mathrm{SD}), \quad{ }^{207} \mathrm{~Pb} /$ ${ }^{204} \mathrm{~Pb}=15.496( \pm 8)$, and ${ }^{208} \mathrm{~Pb} /{ }^{204} \mathrm{~Pb}=36.713( \pm 26)$. 
Table 3. Trace and REEs data by ICP-MS analysis.

\begin{tabular}{|c|c|c|c|c|c|c|}
\hline Sample & 1 & 4 & 5 & 6 & 7 & 10 \\
\hline $\mathrm{Li}(\mathrm{ppm})$ & 32.54 & 7.04 & 9.11 & 10.18 & 36.94 & 24.84 \\
\hline $\mathrm{Be}$ & 0.71 & 4.21 & 0.74 & 0.68 & 1.64 & 1.60 \\
\hline $\mathrm{Sc}$ & 40.95 & 16.50 & 40.43 & 39.61 & 31.85 & 22.83 \\
\hline V & 299.90 & 1.39 & 324.30 & 317.70 & 317.50 & 353.70 \\
\hline $\mathrm{Cr}$ & 188.60 & 3.19 & 99.75 & 132.20 & 517.20 & 22.34 \\
\hline Co & 45.03 & 6.23 & 41.71 & 43.98 & 68.56 & 40.22 \\
\hline $\mathrm{Ni}$ & 48.54 & 0.32 & 51.8 & 49.82 & 310.20 & 26.87 \\
\hline $\mathrm{Rb}$ & 8.60 & 20.31 & 8.44 & 5.42 & 31.70 & 37.56 \\
\hline $\mathrm{Sr}$ & 314.60 & 228.80 & 209.00 & 198.40 & 648.70 & 563.20 \\
\hline Y & 34.88 & 110.60 & 39.25 & 35.08 & 21.40 & 32.19 \\
\hline $\mathrm{Zr}$ & 138.30 & 259.20 & 143.70 & 134.60 & 132.10 & 251.70 \\
\hline $\mathrm{Nb}$ & 8.15 & 22.61 & 7.98 & 7.47 & 29.75 & 26.83 \\
\hline Cs & 0.41 & 0.81 & 0.01 & 0.10 & 4.93 & 3.04 \\
\hline $\mathrm{Ba}$ & 122.30 & 389.90 & 127.50 & 114.60 & 331.90 & 443.10 \\
\hline $\mathrm{La}$ & 14.09 & 53.05 & 9.97 & 9.35 & 26.53 & 33.37 \\
\hline $\mathrm{Ce}$ & 26.63 & 117.40 & 23.32 & 22.34 & 53.20 & 68.96 \\
\hline $\operatorname{Pr}$ & 3.594 & 14.81 & 3.33 & 3.14 & 6.40 & 8.36 \\
\hline $\mathrm{Nd}$ & 16.85 & 63.64 & 16.47 & 15.33 & 26.32 & 34.39 \\
\hline $\mathrm{Sm}$ & 4.73 & 15.30 & 5.08 & 4.72 & 5.450 & 7.327 \\
\hline $\mathrm{Eu}$ & 1.65 & 3.76 & 1.73 & 1.66 & 1.69 & 2.27 \\
\hline $\mathrm{Gd}$ & 5.63 & 16.31 & 6.22 & 5.78 & 5.18 & 6.83 \\
\hline $\mathrm{Tb}$ & 0.95 & 2.86 & 1.08 & 1.01 & 0.76 & 1.05 \\
\hline Dy & 5.85 & 18.09 & 6.70 & 6.13 & 4.19 & 5.90 \\
\hline Ho & 1.17 & 3.78 & 1.36 & 1.24 & 0.78 & 1.13 \\
\hline Er & 3.30 & 11.28 & 3.84 & 3.44 & 2.07 & 3.11 \\
\hline $\mathrm{Tm}$ & 0.48 & 1.68 & 0.55 & 0.50 & 0.28 & 0.45 \\
\hline $\mathrm{Yb}$ & 2.90 & 10.14 & 3.35 & 3.10 & 1.70 & 2.75 \\
\hline $\mathrm{Lu}$ & 0.41 & 1.36 & 0.48 & 0.45 & 0.24 & 0.39 \\
\hline Hf & 3.57 & 6.74 & 3.67 & 3.48 & 3.38 & 6.06 \\
\hline $\mathrm{Ta}$ & 0.59 & 1.74 & 0.59 & 0.55 & 2.06 & 1.94 \\
\hline $\mathrm{Pb}$ & 3.55 & 10.52 & 1.93 & 1.83 & 4.88 & 7.37 \\
\hline $\mathrm{Th}$ & 1.41 & 12.22 & 1.28 & 1.20 & 3.46 & 4.51 \\
\hline $\mathrm{U}$ & 0.20 & 2.63 & 0.27 & 0.24 & 0.72 & 0.76 \\
\hline
\end{tabular}

\section{Mineral chemistry}

Microprobe analyses of phenocryst and groundmass minerals were performed on all samples. Representative average mineral compositions are discussed below.

All samples of the Sylhet Traps contained a wide range of plagioclase compositions $\left(\mathrm{An}_{20-72}\right)$ as listed in table 3. Sample 5 consists of a higher orthoclase percentage $\left(\mathrm{Or}_{66}\right)$, indicating the alkali nature of the magma. However, the matrix of the picrite sample (sample 7) contains higher levels of $\mathrm{An}_{77}$. Samples 1 and 4 have higher albite $\left(\mathrm{Ab}_{92}\right)$ levels in both the phenocryst and groundmass. Pyroxenes from the Sylhet Trap basalts are mostly augites $\left(\mathrm{Wo}_{36-50} \mathrm{En}_{39-50} \mathrm{Fs}_{6-25}\right)$ (figure $3 \mathrm{a}$ ). Pyroxene in sample 7 is diopside with higher $\mathrm{Mg \#}$ 92.5. Moreover, groundmass of sample 6 indicates pigeonite. Most of the samples are rich in $\mathrm{FeO}$ $(\sim 7-18 \%)$ and their $\mathrm{Mg} \#$ ranges from 76 to 82 .
The phenocrysts and groundmasses in samples 5, 6 , and 10 contain 1.85-2.80\% of $\mathrm{Al}_{2} \mathrm{O}_{3}$ and less than $1.6 \%$ of $\mathrm{TiO}_{2}$, a range that corresponds to tholeiitic clinopyroxene (Leterrier et al. 1982). In contrast, pyroxenes in sample 7 have higher $\mathrm{Al}_{2} \mathrm{O}_{3}$, $\mathrm{Na}_{2} \mathrm{O}$, and $\mathrm{CaO}$ content in the pyroxenes that range from $0.23-0.54 \%$ and $9-24 \%$, respectively. The $\mathrm{Ca}+\mathrm{Na}$ vs. Ti diagram (figure $3 \mathrm{~b}$ ) shows that most of the clinopyroxenes represent tholeiitic basalt affinity, excluding sample 7, which displays an alkali basalt. Olivine and spinel were found in the picrite sample (sample 7) as phenocrysts and groundmasses. The phenocrysts are mainly forsterite $\left(\mathrm{Fo}_{89}\right)$ with $48 \% \mathrm{MgO}$. However, the groundmass composition has lower Fo content $\left(\mathrm{Fo}_{46}\right)$. Spinel was identified within olivine phenocrysts as an inclusion, which indicates the primitive nature of the rock. Similar picrite samples are found in places in the Reunion hotspot, which is related to the Deccan Traps of western India 
Table 4. Measured and initial $_{(I)}$ (assumed as $117 \mathrm{Ma}$ ) Sr, Nd and Pb isotopic ratios of Sylhet Traps Basalts.

\begin{tabular}{|c|c|c|c|c|c|c|}
\hline Sample & 1 & 4 & 5 & 6 & 7 & 10 \\
\hline $\mathrm{Rb}(\mathrm{ppm})$ & 8.600 & 20.310 & 8.440 & 5.420 & 31.700 & 37.560 \\
\hline $\mathrm{Sr}(\mathrm{ppm})$ & 314.600 & 228.800 & 209.000 & 198.400 & 648.700 & 563.200 \\
\hline${ }^{87} \mathrm{Rb} /{ }^{86} \mathrm{Sr}$ & 0.079 & 0.257 & 0.117 & 0.079 & 0.141 & 0.193 \\
\hline${ }^{87} \mathrm{Sr} /{ }^{86} \mathrm{Sr}_{(0)}$ & 0.707 & 0.714 & 0.705 & 0.704 & 0.707 & 0.710 \\
\hline${ }^{87} \mathrm{Sr} /{ }^{86} \mathrm{Sr}_{(\mathrm{I})}$ & 0.707 & 0.714 & 0.704 & 0.704 & 0.706 & 0.710 \\
\hline$\varepsilon_{\mathrm{Sr}(\mathrm{I})}$ & 37.300 & 130.700 & -0.100 & -0.200 & 30.200 & 81.100 \\
\hline $\mathrm{Sm}(\mathrm{ppm})$ & 4.730 & 15.300 & 5.080 & 4.720 & 5.450 & 7.330 \\
\hline $\mathrm{Nd}(\mathrm{ppm})$ & 16.850 & 63.640 & 16.470 & 15.330 & 26.320 & 34.390 \\
\hline${ }^{147} \mathrm{Sm} /{ }^{144} \mathrm{Nd}$ & 0.170 & 0.145 & 0.186 & 0.186 & 0.125 & 0.129 \\
\hline${ }^{143} \mathrm{Nd} /{ }^{144} \mathrm{Nd}_{(0)}$ & 0.513 & 0.512 & 0.513 & 0.513 & 0.513 & 0.512 \\
\hline${ }^{143} \mathrm{Nd} /{ }^{144} \mathrm{Nd}(\mathrm{I})$ & 0.512 & 0.512 & 0.513 & 0.513 & 0.513 & 0.512 \\
\hline$\varepsilon_{\mathrm{Nd}(\mathrm{I})}$ & -0.600 & -10.300 & 3.300 & 3.100 & 2.000 & -6.000 \\
\hline $\mathrm{U}(\mathrm{ppm})$ & 0.200 & 2.630 & 0.270 & 0.240 & 0.720 & 0.760 \\
\hline $\mathrm{Th}(\mathrm{ppm})$ & 1.410 & 12.220 & 1.280 & 1.200 & 3.460 & 4.510 \\
\hline $\mathrm{Pb}(\mathrm{ppm})$ & 3.550 & 10.520 & 1.930 & 1.830 & 4.880 & 7.370 \\
\hline${ }^{206} \mathrm{~Pb} /{ }^{204} \mathrm{~Pb}_{(0)}$ & & 19.035 & 18.081 & 18.079 & 19.884 & 18.363 \\
\hline${ }^{207} \mathrm{~Pb} /{ }^{204} \mathrm{~Pb}_{(0)}$ & & 15.650 & 15.571 & 15.573 & 15.719 & 15.760 \\
\hline${ }^{208} \mathrm{~Pb} /{ }^{204} \mathrm{~Pb}_{(0)}$ & & 39.129 & 38.369 & 38.370 & 39.979 & 40.204 \\
\hline${ }^{238} \mathrm{U} /{ }^{204} \mathrm{~Pb}$ & & 15.431 & 8.635 & 8.095 & 9.107 & 6.365 \\
\hline${ }^{235} \mathrm{U} /{ }^{204} \mathrm{~Pb}$ & & 0.112 & 0.063 & 0.059 & 0.066 & 0.046 \\
\hline${ }^{232} \mathrm{Th} /{ }^{204} \mathrm{~Pb}$ & & 74.089 & 42.301 & 41.824 & 45.223 & 39.031 \\
\hline${ }^{206} \mathrm{~Pb} /{ }^{204} \mathrm{~Pb}_{(\mathrm{I})}$ & & 18.752 & 17.923 & 17.931 & 19.717 & 18.246 \\
\hline${ }^{207} \mathrm{~Pb} /{ }^{204} \mathrm{~Pb}(\mathrm{I})$ & & 15.636 & 15.563 & 15.566 & 15.711 & 15.754 \\
\hline${ }^{208} \mathrm{~Pb} /{ }^{204} \mathrm{~Pb}(\mathrm{I})$ & & 38.699 & 38.123 & 38.127 & 39.716 & 39.977 \\
\hline
\end{tabular}

(Krishnamurthy et al. 2000). The spinel contains significant amounts of $\mathrm{Cr}(45.99 \%)$ and $\mathrm{FeO}$ $(29.68 \%)$. Amphiboles were observed in samples 4 and 10. Sample 4 contains a large amount of amphiboles megaphenocrysts with $>29 \%$ of $\mathrm{FeO}$; whereas, a very small amount of amphibole is present as groundmass in sample 10. Ilmenite is common in most samples, excluding sample 7 , as groundmass. However, sample 4 contains ilmenite and magnetite as phenocrysts with higher $\mathrm{TiO}_{2}$ $(\sim 50 \%)$ and $\mathrm{FeO}(\sim 93 \%)$. Ilmenites within samples 1 and 5 have a very high $\mathrm{FeO}(>68 \%)$ content.

\section{Geochemistry}

\subsection{Whole-rock geochemistry}

Major and trace element data for six samples are presented in table 2 . In the total alkali vs. silica (TAS) classification diagram (figure 4a) of Le Maitre et al. (2002), Sylhet Trap rocks display diverse chemical composition from picro-basalt (sample 7), basalt (samples 1 and 10), basaltic andesite (samples 5 and 6) to dacite (sample 4), and they mostly fall in the subalkaline field. The subalkaline nature of the investigated rocks is also indicated by their CIPW-normative composition (table 2). Furthermore, the $\mathrm{SiO}_{2}-\mathrm{K}_{2} \mathrm{O}$ diagram has two distinct trends: samples $1-6$ plot near the boundary between the low $\mathrm{K}$ and medium $\mathrm{K}$ series; samples 7 and 10 plot near the boundary between the medium $\mathrm{K}$ and high $\mathrm{K}$ series (figure $4 \mathrm{~b}$ ). Only sample 7 contains nepheline, indicative of an alkaline nature. All samples have an average $10 \%$ of magnetite and ilmenite in their normative composition. Sample 7 has a higher Mg number (73.53) and $\mathrm{MgO}$ (12.29), indicating that this sample has a primitive nature (Green 1971; Luhr 1997; Velasco-Tapia and Verma 2001; Srivastava and Sinha 2007). The other samples have a lower $\mathrm{Mg}$ number ( 50-60), suggesting that they are a differentiated product of primary magma that may have experienced some degree of olivine and Cpx fractionation.

The variation diagrams (figure $5 \mathrm{a}-\mathrm{b}$ ) between $\mathrm{MgO}$ and other oxides indicate two different trends. For example, $\mathrm{TiO}_{2}$ has a negative correlation with $\mathrm{MgO}$ content whereas $\mathrm{CaO}$ has a positive correlation in samples 7 and 10. Samples 1, 5, and 6 have a negative correlation between $\mathrm{MgO}$ and $\mathrm{CaO}$ and a positive correlation between $\mathrm{MgO}$ and $\mathrm{TiO}_{2}$. The diagram (figure $5 \mathrm{c}-\mathrm{d}$ ) between $\mathrm{Mg}$ number $(\mathrm{Mg} \#)$ and selected trace elements $(\mathrm{Zr}$ and $\mathrm{Nb})$ also has two distinct trends. Samples 7 and 10 have 


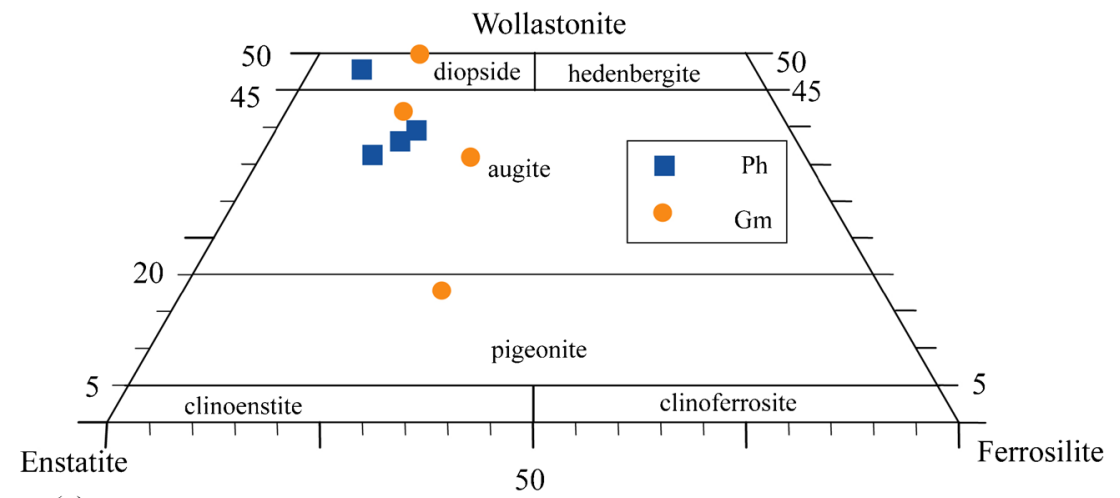

(a)

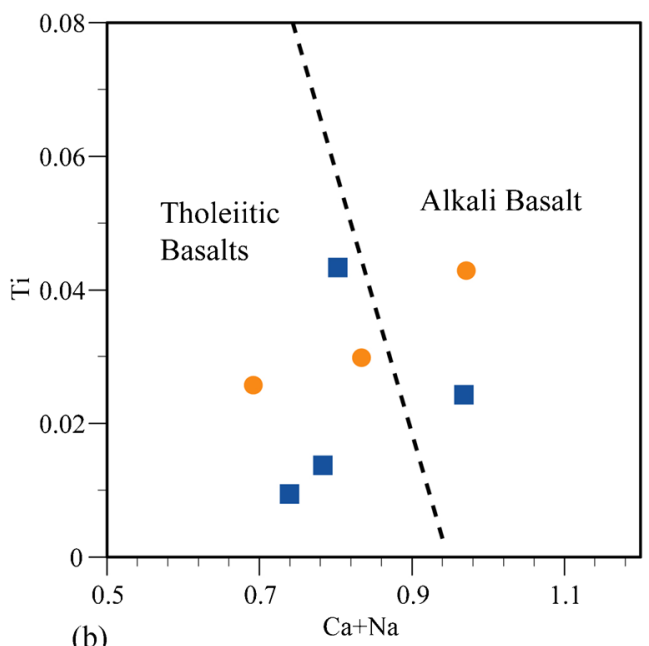

(b)

Figure 3. (a) Wollastonite-enstatite-ferrosilite classification diagram for pyroxenes (after Morimoto et al. 1988). (b) Ca+Na vs. Ti diagram (Leterrier et al. 1982) for basalt classification using Cpx.

negative correlations between $\mathrm{Zr}$ and $\mathrm{Mg} \#$, but no correlation between $\mathrm{Nb}$ and $\mathrm{Mg} \#$.

Chondrite-normalized REE plots are shown in figure 6(a). The LREE/HREE is generally higher in samples 7 and 10 compared with samples 1 , 5 , and 6 . A negative Eu anomaly $\left(\mathrm{Eu} / \mathrm{Eu}^{*}=0.73\right)$ is observed in sample 4, suggesting possible plagioclase fractionation and/or crustal contamination. Our results are consistent with the field of the Rajmahal (Kent et al. 1997) and STGB (Ghatak and Basu 2011, 2013), with the exception of sample 4.

The two distinct groups of basalts are illustrated in the primitive mantle-normalized incompatible element pattern (figure 6b). The patterns broadly resemble OIB pattern and correspond to the field of the Rajmahal Traps (Storey et al. 1992; Kent et al. 1997), the Kerguelen Plateau (Weis et al. 2001; Ingle et al. 2002; Kurnosov et al. 2003) and the STGB (Ghatak and Basu 2011). Samples 7 and 10 display marked enrichments in trace elements compared with samples 1,5 , and 6 . The patterns are characterized by pronounced positive $\mathrm{Pb}$ anomalies, but do not display significant enrichment in HFSE ( $\mathrm{Nb}$ and $\mathrm{Ta}$ ) relative to LREE and LILE.
Sample 4 shows marked negative anomalies of $\mathrm{K}$, Sr, $\mathrm{P}$ and Ti.

\subsection{Sr-Nd-Pb isotope geochemistry}

$\mathrm{Sr}-\mathrm{Nd}-\mathrm{Pb}$ isotopic analyses are presented in table 4 and plotted in figure 7 in comparison with the STGB (Ghatak and Basu 2011, 2013), the Rajmahal Traps (Storey et al. 1992; Kent et al. 1997), the Kerguelen Plateau (Weis et al. 2001; Ingle et al. 2002; Kurnosov et al. 2003), and the Ninety-East Ridge (Mahoney et al. 2002). ${ }^{87} \mathrm{Sr} /{ }^{86} \mathrm{Sr}_{(\mathrm{I})}$ and ${ }^{143} \mathrm{Nd} /{ }^{144} \mathrm{Nd} \mathrm{d}_{(\mathrm{I})}$ range from 0.70435 to 0.71357 and 0.51196 to 0.51266 , respectively. As shown in figure $7(\mathrm{c})$, the data define a linear trend between HIMU and EM-II mantle end member (Zindler and Hart 1986). Most of the data show a similar trend with the STGB and the Kerguelen Plateau basalt, but display higher ${ }^{87} \mathrm{Sr} /{ }^{86} \mathrm{Sr}$ and lower ${ }^{143} \mathrm{Nd} /{ }^{144} \mathrm{Nd}$ than the NinetyEast Ridge basalts.

The plot of ${ }^{206} \mathrm{~Pb} /{ }^{204} \mathrm{~Pb}_{(\mathrm{I})}$ vs. ${ }^{207} \mathrm{~Pb} /{ }^{204} \mathrm{~Pb}_{(\mathrm{I})}$ (figure $7 \mathrm{a}$ ) shows that samples 5 and 6 have lower values and fall within the field of the Kerguelen 


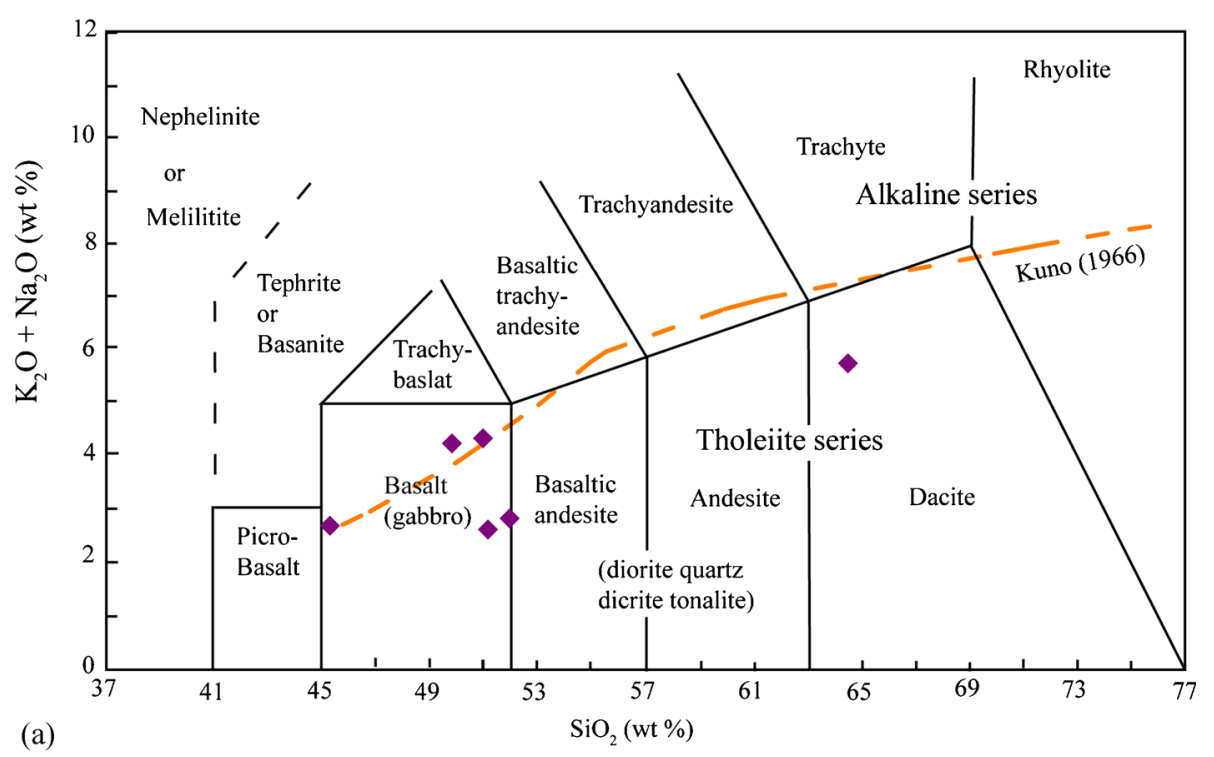

(a)

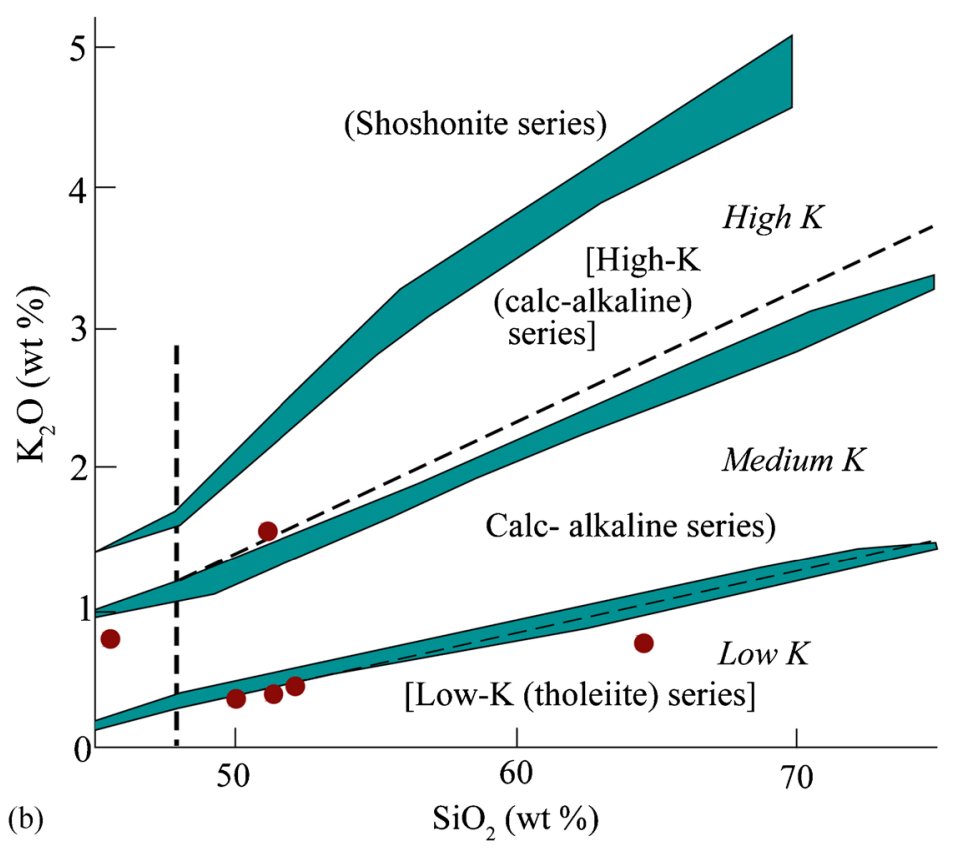

Figure 4. (a) TAS diagram for igneous rock classification (Le Maitre et al. 2002). (b) Plot of $\mathrm{SiO}_{2}$ vs. $\mathrm{K}_{2} \mathrm{O}$.

Plateau, the Rajmahal Traps and the STGB. In contrast, sample 10 has higher ${ }^{207} \mathrm{~Pb} /{ }^{204} \mathrm{~Pb}_{(\mathrm{I})}$ and plots close to the field of the Ninety-East Ridge of the Indian Ocean (Mahoney et al. 2002) and upper crustal field (Chakrabarti et al. 2011) and is close to ancient non-volcanic continental clasts from ODP site 1137 (Ingle et al. 2002). Samples 4 and 7 show EM-II and HIMU-type characteristics with higher ${ }^{206} \mathrm{~Pb} /{ }^{204} \mathrm{~Pb}_{(\mathrm{I})}$. The ${ }^{206} \mathrm{~Pb} /{ }^{204} \mathrm{~Pb}_{(\mathrm{I})}$ vs. ${ }^{208} \mathrm{~Pb} /{ }^{204} \mathrm{~Pb}_{(\mathrm{I})}$ plot has a similar pattern as figure 7(b). Samples 5 and 6 fall within the field of the STGB, the Rajmahal Traps and the Kerguelen Plateau with lower ${ }^{208} \mathrm{~Pb} /{ }^{204} \mathrm{~Pb}_{(\mathrm{I})}$. Samples 4, 7, and 10 have higher ${ }^{208} \mathrm{~Pb} /{ }^{204} \mathrm{~Pb}_{(\mathrm{I})}$ and are distinct from any compared fields. Sample 10 has a resemblance to ODP site 1137 samples.

\section{Discussion}

The Sylhet Trap basalts can be correlated with basalts at the Rajmahal Traps (Storey et al. 1992; Kent et al. 1997) and the Kerguelen Plateau (Weis et al. 2001; Ingle et al. 2002; Kurnosov et al. 2003), having similar age and geochemical compositions (Ghatak and Basu 2011, 2013). Here we will discuss the petrography and mineralogy, geochemistry, $\mathrm{Nd}-\mathrm{Sr}-\mathrm{Pb}$ isotope geochemistry, and $\mathrm{K}-\mathrm{Ar}$ dating for a primitive sample (sample 7) as presented in the results section. We explore some salient features of the geodynamic setting and mantle source characterization of the Sylhet Trap rocks and compare our data with the STGB, the Rajmahal Traps, and the Kerguelen Plateau basalts. 

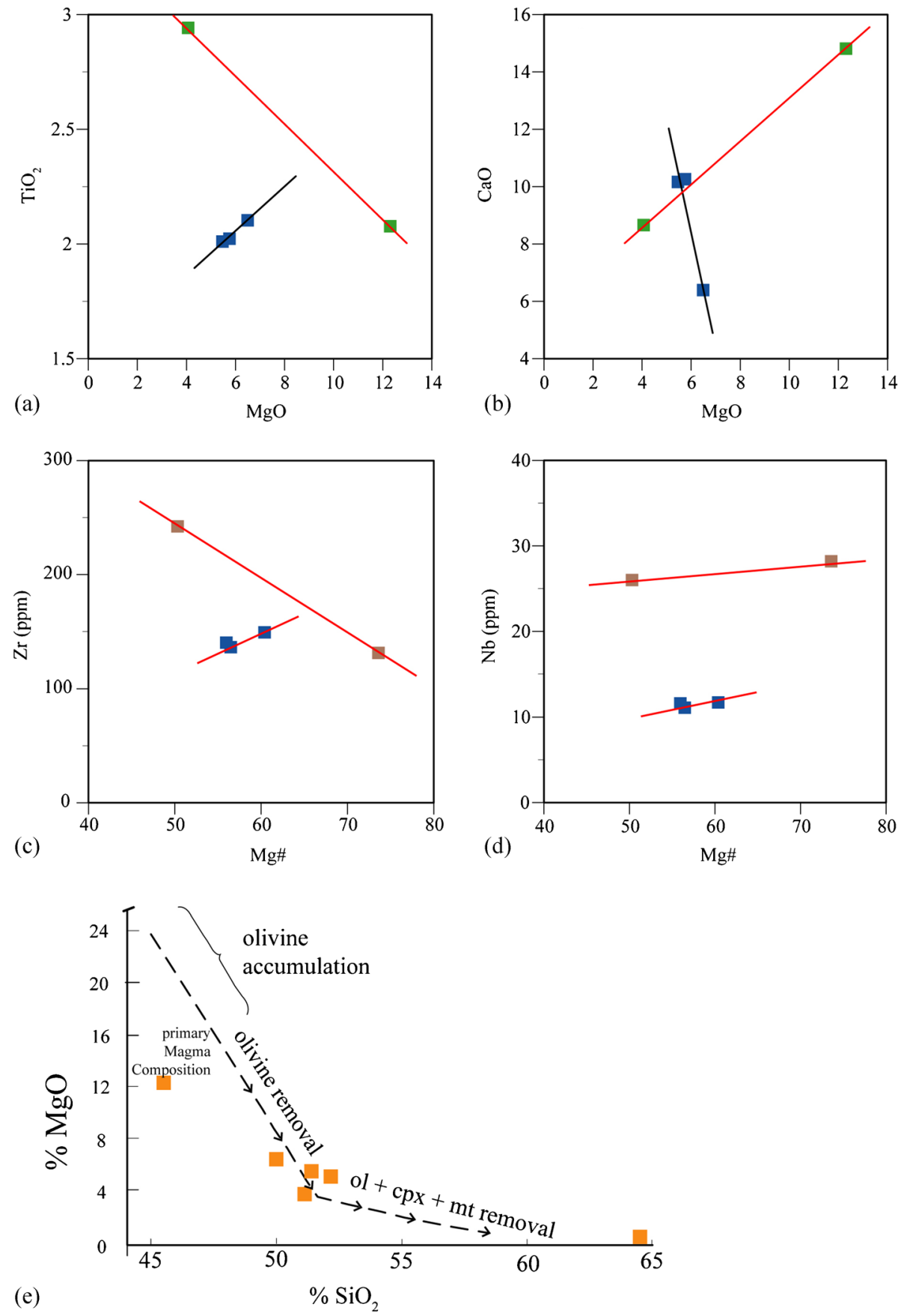

Figure 5. Variation diagrams between $\mathrm{MgO}$ and other oxides and $\mathrm{Mg} \#$ and other incompatible trace elements.

\subsection{Mantle source characterization}

Trace elements and isotopic data from our analyses suggest at least two mantle components were involved in magma generation for the Sylhet Traps: (i) the Kerguelen plume-like component and (ii) HIMU-type component. Moreover, an upper continental contamination is evident in the generation of the Sylhet Trap magmas. These issues are further described in the following sections.

\subsubsection{Kerguelen plume-like component}

The Kerguelen plume is represented mostly by basalts from ODP sites 1138, 1141, and 1142. These samples are characterized by relatively uncontaminated lava and less enrichment of incompatible trace elements (Neal et al. 2002). The Rajmahal Group I and samples from the $\mathrm{CH}$ section of Sylhet Traps (Ghatak and Basu 2011) also exhibit similar characteristics, indicating the same plume component as these areas. Ghatak and Basu (2011) 

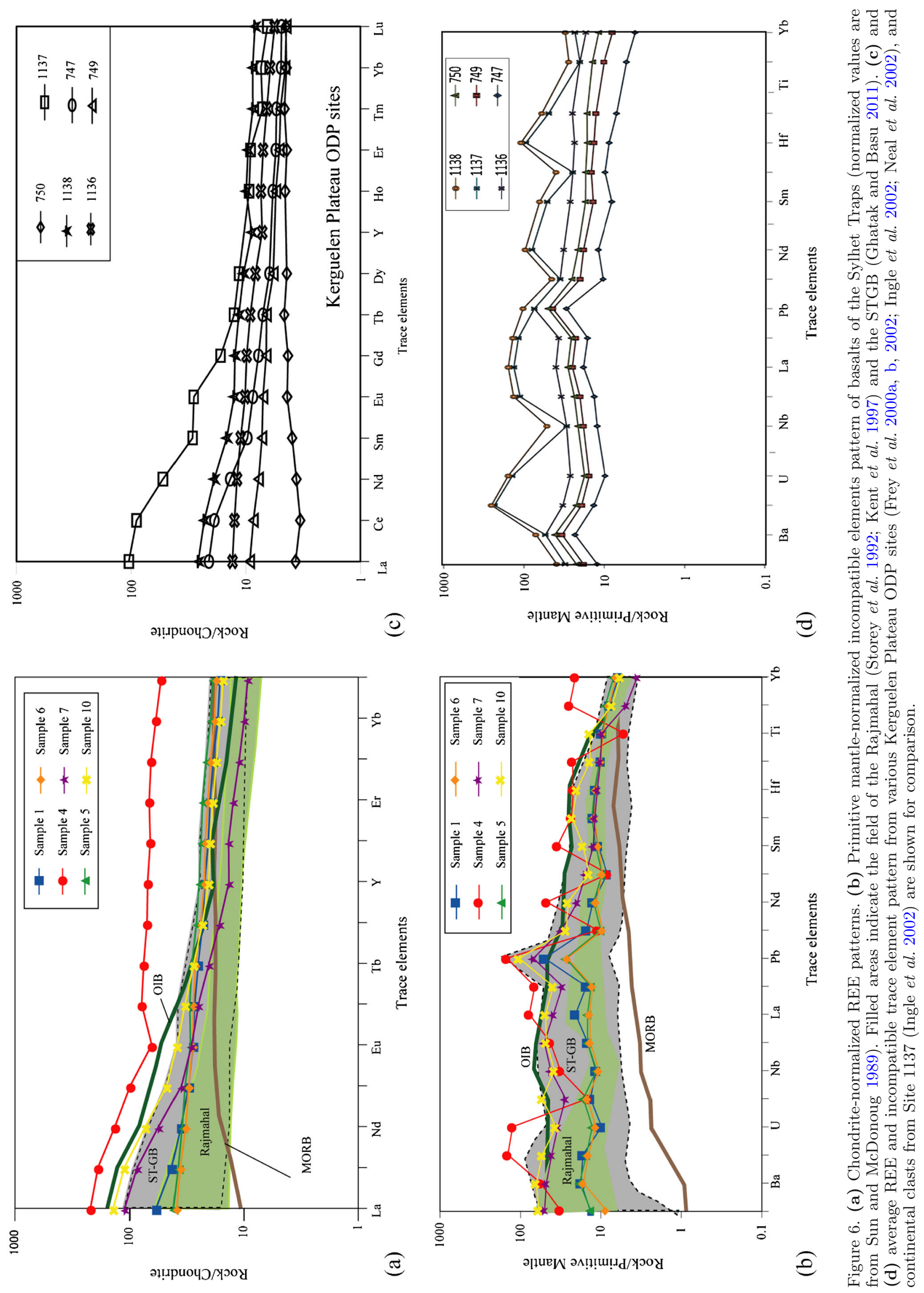

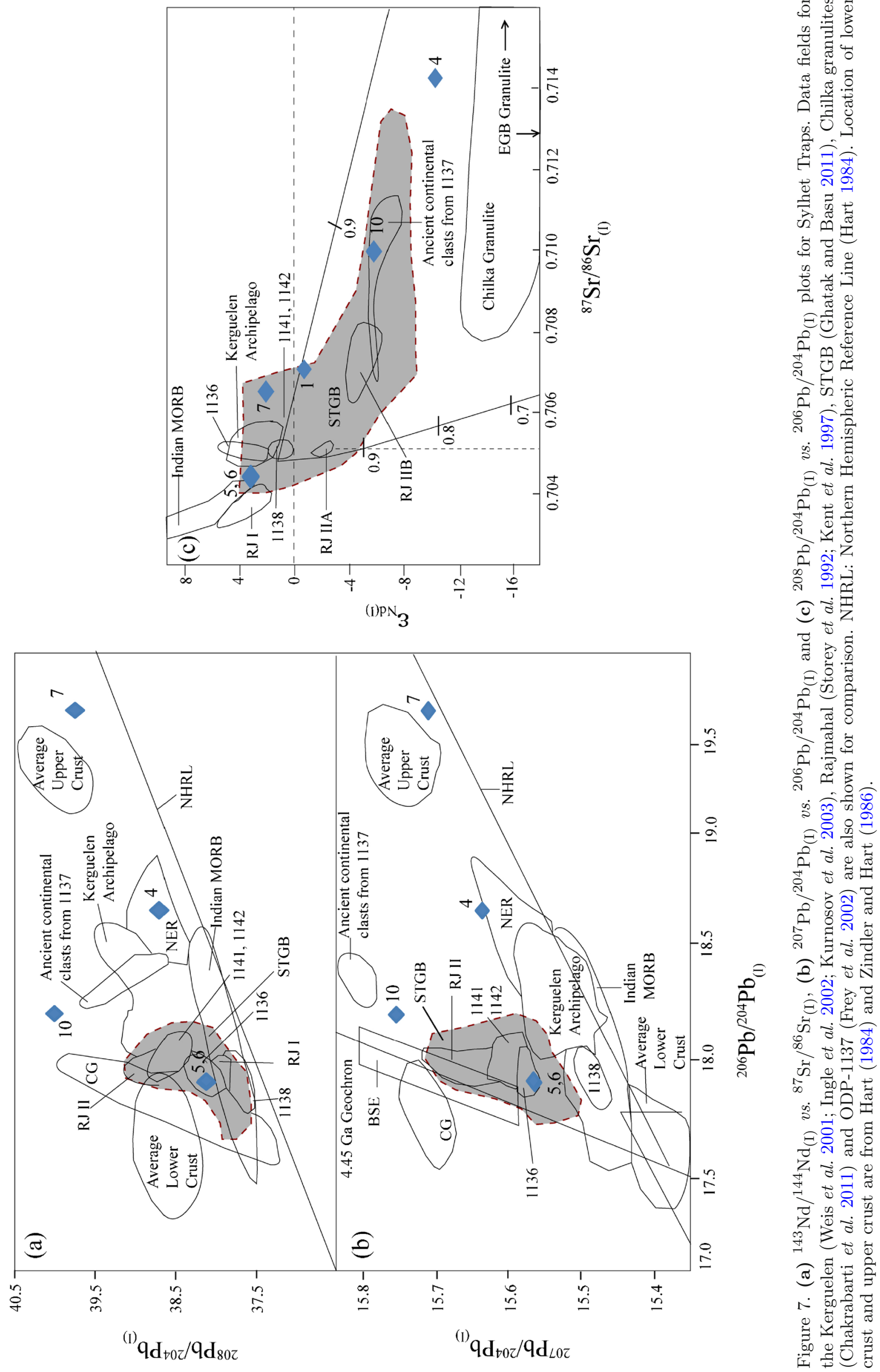
proposed that the Kerguelen plume-head composition in $\mathrm{Nd}$-Sr-isotopic space has $\varepsilon \mathrm{Nd}_{(\mathrm{I})}=+2.0$ and ${ }^{87} \mathrm{Sr} /{ }^{86} \mathrm{Sr}_{(\mathrm{I})}=0.7046$, which is in excellent agreement with the average value for site 1138 basalts $\left(\varepsilon \mathrm{Nd}_{(\mathrm{I})}=+0.6\right.$ and $\left.{ }^{87} \mathrm{Sr} /{ }^{86} \mathrm{Sr}_{(\mathrm{I})}=0.7048\right)$ and was suggested to be representative of the Kerguelen starting plume-head by Neal et al. (2002). Sr-Nd isotopic compositions (figure 7c) and the incompatible trace element pattern and the rare-earth element pattern of samples 5 and 6 closely resemble those of the Rajmahal Group I and most of the $\mathrm{CH}$ section of the STGB (figure 2 of Ghatak and Basu 2011) (figure 6). In addition, ${ }^{208} \mathrm{~Pb} /{ }^{204} \mathrm{~Pb}_{(\mathrm{I})}$, ${ }^{207} \mathrm{~Pb} /{ }^{204} \mathrm{~Pb}_{(\mathrm{I})}$, and ${ }^{206} \mathrm{~Pb} /{ }^{204} \mathrm{~Pb}_{(\mathrm{I})}$ of these two samples fall within the field of Kerguelen (Weis et al. 2001; Ingle et al. 2002; Kurnosov et al. 2003) and the Rajmahal Group I (Storey et al. 1992; Kent et al. 1997), and the STGB (Ghatak and Basu 2011) (figure $7 \mathrm{~b}-\mathrm{c}$ ). The plot of $\varepsilon \mathrm{Nd}_{(\mathrm{I})}$ vs. ${ }^{87} \mathrm{Sr} /{ }^{86} \mathrm{Sr}_{(\mathrm{I})}$ also demonstrates the similar properties of samples 5 and 6 and these three fields (figure 7c). Therefore, we propose that in samples 5 and 6 , the basalt magma was derived from the primitive Kerguelen plume source.

\subsubsection{HIMU-type component}

Picritic sample (sample 7) has higher values of ${ }^{208} \mathrm{~Pb} /{ }^{204} \mathrm{~Pb}_{(\mathrm{I})},{ }^{207} \mathrm{~Pb} /{ }^{204} \mathrm{~Pb}_{(\mathrm{I})}$, and ${ }^{206} \mathrm{~Pb} /{ }^{204} \mathrm{~Pb}_{(\mathrm{I})}$ (39.716, 15.711 and 19.717), which fall between the EMII and HIMU mantle components of Zindler and Hart (1986). High ${ }^{206} \mathrm{~Pb} /{ }^{204} \mathrm{~Pb}_{(\mathrm{I})}$ and ${ }^{208} \mathrm{~Pb} /{ }^{204} \mathrm{~Pb}_{(\mathrm{I})}$ suggest either HIMU (of OIB) components in their source (e.g., St. Helena (Chaffey et al. 1989), Mangaia (Saunders et al. 1988) or crust contamination (e.g., Hercinian granite, Vitrac et al. 1981)). Sample 7 is characterized by the content of fresh $\mathrm{Mg}$-rich olivine $\left(\mathrm{Fo}_{89}\right)$ with Cr-spinel inclusion (figure 2e) and high bulk Mg\#, which indicate its primitive nature. Therefore, a model for HIMU character caused by upper crustal contamination (or sediment involvement) can be rejected; instead, we propose that there are HIMU characteristics in the mantle source. This HIMU component in primitive rock has not been reported from the STGB (Ghatak and Basu 2011, 2013), the Rajmahal Traps (Storey et al. 1992; Kent et al. 1997) and the Kerguelen (Weis et al. 2001; Ingle et al. 2002; Kurnosov et al. 2003). The plot of $\mathrm{Ba} / \mathrm{Nb}$ vs. $\mathrm{Zr} / \mathrm{Nb}$ (figure $8 \mathrm{~b}$ ) also indicates that picritic sample 7 has a HIMU affinity and its $\mathrm{Zr} / \mathrm{Nb}$ is similar to those of the St. Helena basalts (Weaver 1991).

Whether this HIMU component was inherited from the Kerguelen plume heterogeneity requires further data collection from the region affected by the Kerguelen plume. Sample 7 was dated at
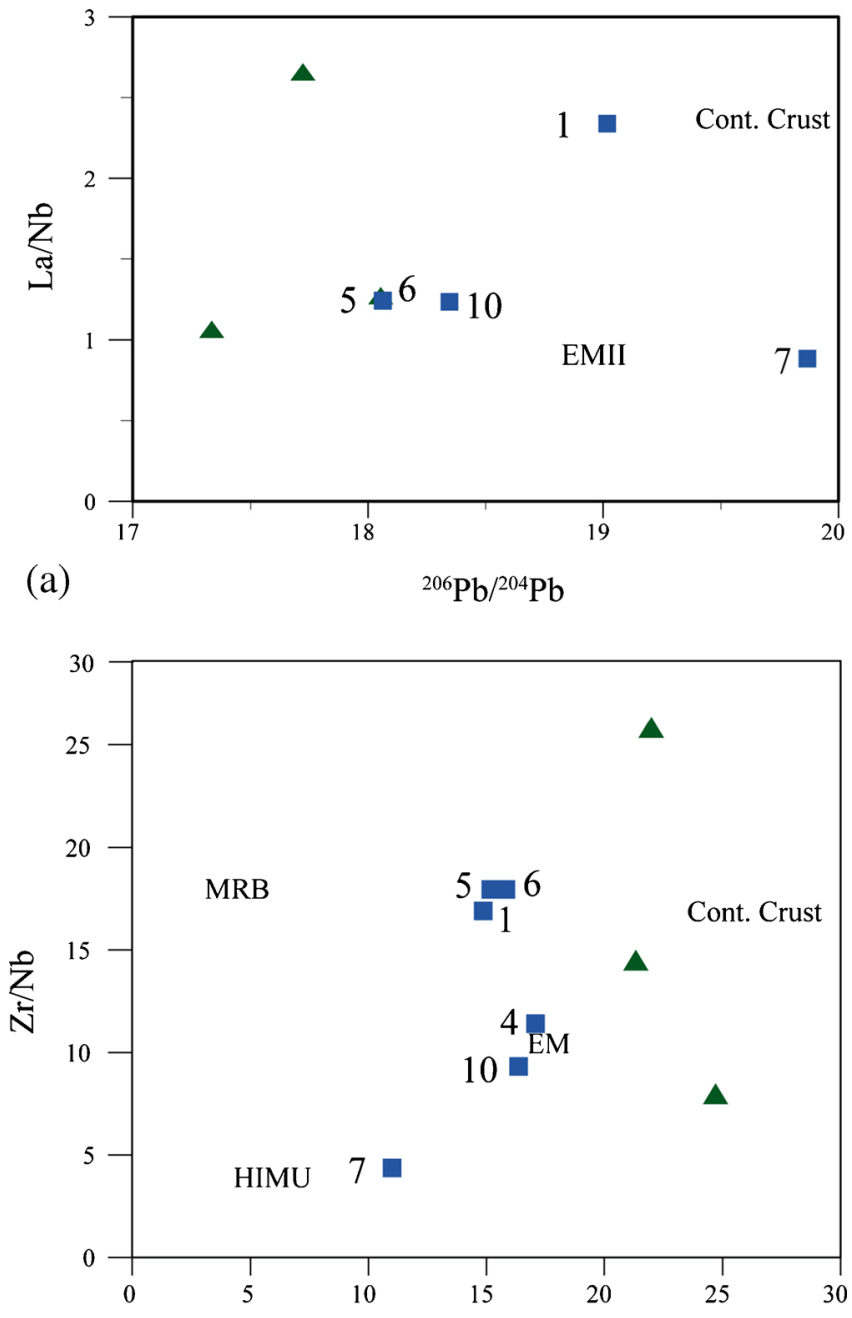

(b)

$\mathrm{Ba} / \mathrm{Nb}$

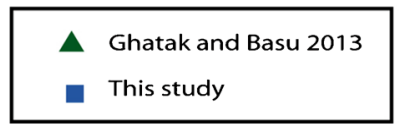

Figure 8. (a) La/Nb vs. ${ }^{206} \mathrm{~Pb} /{ }^{204} \mathrm{~Pb}_{(\mathrm{I})}$ and (b) $\mathrm{Zr} / \mathrm{Nb}$ vs. $\mathrm{Ba} / \mathrm{Nb}$, illustrating the mantle components for Sylhet Traps compared with samples from Borako dyke (Ghatak and Basu 2013). Locations of MORB, EM, HIMU and continental crust are from Hart (1984) and Zindler and Hart (1986).

$\sim 84 \mathrm{Ma}$, which also supports further study of the adjoining location where our sample was collected.

\subsubsection{Upper continental source}

The upper continental crust is characterized by enrichment of LREE and high ${ }^{87} \mathrm{Sr} /{ }^{86} \mathrm{Sr}$, ${ }^{208} \mathrm{~Pb} /{ }^{204} \mathrm{~Pb},{ }^{207} \mathrm{~Pb} /{ }^{204} \mathrm{~Pb}$, and ${ }^{206} \mathrm{~Pb} /{ }^{204} \mathrm{~Pb}$, and low ${ }^{143} \mathrm{Nd} /{ }^{144} \mathrm{Nd}$ values (Weaver 1991). Ghatak and Basu (2011) reported that Sylhet Traps from the MB section are contaminated by lower continental crust (granulite metamorphism) and are comparable to the Chilka granulite (Chakrabarti et al. 2011) or the Eastern Ghat granulites 
(Rickers et al. 2001). Our analyses demonstrated that sample 10 exhibits an enrichment of REE (figure 5), which is comparable with an ancient continental fragment from ODP site 1137 (Ingle et al. 2002) in the Kerguelen Plateau. Few samples from the STGB (Ghatak and Basu 2011, 2013) have similar characteristics. In figure 8(b), sample 10 has an association with continental crust (Weaver 1991) and is consistent with a few dyke samples reported in Ghatak and Basu (2013) from the Bokaro coal field of Bihar-West Bengal. The high ${ }^{87} \mathrm{Sr} /{ }^{86} \mathrm{Sr}_{(\mathrm{I})}$ $(0.71008)$ and low ${ }^{143} \mathrm{Nd} /{ }^{144} \mathrm{Nd}_{(\mathrm{I})}(0.51218)$ values of sample 10 (figure 7c) suggest involvement of the upper continental crust component and are comparable with the STGB (Ghatak and Basu 2011, 2013) and ODP 1137 (Ingle et al. 2002). Moreover, high ${ }^{208} \mathrm{~Pb} /{ }^{204} \mathrm{~Pb}_{(\mathrm{I})}$, and ${ }^{207} \mathrm{~Pb} /{ }^{204} \mathrm{~Pb}_{(\mathrm{I})}$ (figure $7 \mathrm{~b}$ ) values fully support upper crustal source involvement in sample 10. Therefore, it may be concluded that the Sylhet Trap rocks experienced both lower crustal (Ghatak and Basu 2011) and upper crustal contamination (Ghatak and Basu 2013).

\section{Conclusion}

Petrographic, geochemical, and isotopic analyses of the Sylhet Traps from the eastern Shillong Plateau indicate two suites of magma, MORB-like tholeiitic basalt for samples 1,5 and 6 and OIB-like medium to high $\mathrm{K}$ basalts. Sample 4 (dacite) is an EMII type with negative anomalies of $\mathrm{K}, \mathrm{Sr}$, $\mathrm{P}$, and $\mathrm{Ti}$, and low ${ }^{143} \mathrm{Nd} /{ }^{144} \mathrm{Nd}_{(\mathrm{I})}(0.51196)$, suggesting a major involvement of crustal components. The olivine-rich, primitive sample (sample 7) has a HIMU-type mantle component. This sample was dated to $84.0 \pm 1.9 \mathrm{Ma}$ by the $\mathrm{K}-\mathrm{Ar}$ method, indicating that the Sylhet basalt was not emplaced at $\sim 117 \mathrm{Ma}$ in the Shillong Plateau and that its activity continued for $\sim 30$ m.y. Samples 5 and 6 indicate that the Kerguelen plume-like component is analogous to Rajmahal Traps Group I. Sample 10 indicated that it had upper continental crust involvement supported by an enrichment of light rare earth elements and high ${ }^{87} \mathrm{Sr} /{ }^{86} \mathrm{Sr}_{(\mathrm{I})}(0.71008)$, ${ }^{208} \mathrm{~Pb} /{ }^{204} \mathrm{~Pb}_{(\mathrm{I})}$ (39.977), ${ }^{207} \mathrm{~Pb} /{ }^{204} \mathrm{~Pb}_{(\mathrm{I})}$ (15.754), and ${ }^{206} \mathrm{~Pb} /{ }^{204} \mathrm{~Pb}_{(\mathrm{I})}(18.246)$, and low ${ }^{143} \mathrm{Nd} /{ }^{144} \mathrm{Nd}$ (0.51218).

\section{Acknowledgements}

Authors are grateful to S Ohde (University of the Ryukyus) for providing accesses to TIMS and ICPMS. Thoughtful and constructive comments by two anonymous referees have substantially improved the manuscript. This work was supported by a
Grant-in-Aid for Scientific Research (C; 21540496 and 25400519 to RS).

\section{References}

Baksi A K, Barman T R, Paul D K and Farrar E 1987 Widespread Early Cretaceous flood basalt volcanism in eastern India: Geochemical data from the RajmahalBengal-Sylhet Traps; Chem. Geol. 63 133-141.

Baksi A K 1995 Petrogenesis and timing of volcanism in the Rajmahal flood basalt province, northeast India; Chem. Geol. 121 73-90.

Bilham R and England P 2001 Plateau 'pop up' in the great 1897 Assam earthquake; Nature 410 806-809.

Biswas S and Grasemann B 2005 Quantitative morphotectonics of the southern Shillong Plateau (Bangladesh/ India); Austr. J. Earth Sci. 97 82-93.

Chaffey D J, Cliff R A and Wilson B M 1989 Characterization of the St. Helena magma source; Geol. Soc. London, Spec. Publ. 42 257-276.

Chakrabarti R, Basu A R, Bandyopadhyay P K and Zou H 2011 Age and origin of the Chilka anorthosites, eastern Ghats, India: Implications for massif anorthosite petrogenesis and break-up of Rodinia; In: Topics in Igneous Petrology (ed.) Ray J S et al., Springer Science, pp. 355-382.

Chen P and Molnar P 1990 Source parameters of earthquakes and interplate deformation beneath the Shillong Plateau and the northern Indo-Burman ranges; J. Geophys. Res. 95 12,527-12,552.

Coffin M F, Pringle M S, Duncan R A, Gladczenko T P, Storey M, Muller R D and Gahagan L A 2002 Kerguelen hotspot magma output since $130 \mathrm{Ma}$; J. Petrol. 43 1121-1139.

Evans P 1964 The tectonic framework of Assam; J. Geol. Soc. India 5 80-96.

Frey F A, Coffin M F, Wallace P J, Weis D and Zhao X 2000a Origin and evolution of a submarine large igneous province: The Kerguelen Plateau and Broken Ridge, southern Indian Ocean; Earth Planet Sci. Lett. 176 $73-89$.

Frey F A, Weis D, Yang H-J, Nicolaysen K E, Leyrit H and Gire A 2000b Temporal geochemical trends in Kerguelen Archipelago basalts: Evidence for decreasing magma supply from the Kerguelen plume; Chem. Geol. 164 61-80.

Frey F A, Wei D, Borisova A Y and Xu G 2002 Involvement of continental crust in the formation of the Cretaceous Kerguelen Plateau: New perspectives from ODP leg 120 sites; J. Petrol. 43 1207-1239.

Ghatak A and Basu A R 2011 Vestiges of the Kerguelen plume in the Sylhet Traps, northeastern India; Earth Planet Sci. Lett. 308 52-64.

Ghatak A and Basu A R 2013 Isotopic and trace element geochemistry of alkalic-mafic-ultramafic-carbonatitic complexes and flood basalts in NE India: Origin in a heterogeneous Kerguelen plume; Geochim. Cosmochim. Acta 115 46-72.

Ghosh S, Chakraborty S, Balla J K, Paul D K, Sarma A, Bishui P K and Gupta S N 1994 New Rb-Sr isotopic ages and geochemistry of granitoids from Meghalaya and their significance in middle to late Proterozoic crustal evolution; Indian Mineral. 48(No. 53).

Green D H 1971 Composition of basaltic magmas as indicator of conditions of origin: Application to oceanic volcanism; Phil. Trans. Roy. Soc. London, Ser. A 268 707-725. 
Gupta R P and Sen A K 1988 Imprints of Ninety-East Ridge in the Shillong Plateau Indian Shield; Tectonophys. 154 $335-341$.

Hart S R 1984 A large scale isotope anomaly in the Southern Hemisphere; Nature 309 753-759.

Hiller K and Elahi M 1984 Structural development and hydrocarbon entrapment in the Surma Basin, Bangladesh (Northwest Indo-Burman Fold Belt), paper presented at 5th Offshore Southeast Asia Conference, Offshore Southeast Asia Petroleum Limited, Singapore.

Ingle S, Weis D and Frey F A 2002 Indian continental crust recovered from Elan Bank, Kerguelen Plateau (ODP Leg 183, Site 1137); J. Petrol. 43 1241-1257.

Islam M S, Shinjo R and Kayal J R 2010 The tectonic stress field and deformation pattern of northeast India, the Bengal basin and the Indo-Burma ranges: A numerical approach; J. Asian Earth Sci 40(1) 121-131, doi: 10.1016/j.jseaes.2010.08.015.

Islam M S, Shinjo R and Kayal J R 2011 Pop-up tectonics of the Shillong Plateau in northeastern India: Insight from numerical simulations; Gondwana Res 20 395-404, doi: 10.1016/j.gr.2010.11.007.

Itaya T, Nagao K, Inoue K et al. 1991 Argon isotope analysis by a newly developed mass spectrometric system for $\mathrm{K}$ Ar dating; Mineral. J. 15 203-221.

Johnson S Y and Alam A M N 1991 Sedimentation and tectonics of the Sylhet trough, Bangladesh; Geol. Soc. Am. Bull. 103 1513-1527.

Kayal J R 2001 Microearthquake activity in some parts of the Himalaya and the tectonic model; Tectonophys. 339 331-351.

Kent R W, Saunders A D, Kempton P D and Ghose N C (eds) 1997 Rajmahal basalts, eastern India: Mantle sources and melt distribution at a volcanic rifted margin; Geophys Mono (AGU) Washington DC, pp. 145-182.

Kent R W, Pringle M S, Muller R D, Saunders A D and Ghose N C $2002{ }^{40} \mathrm{Ar} /{ }^{39} \mathrm{Ar}$ geochronology of the Rajmahal basalts, India, and their relationship to the Kerguelen Plateau; J. Petrol. 43 1141-1153.

Krishnamurthy P, Gopalan K and Macdougall J D 2000 Olivine compositions in picrite basalts and the Deccan volcanic cycle; J. Petrol. 41 1057-1069.

Kurnosov V, Zolotarev B P, Artamonov A, Garanina S, Petrova V V, Eroshchev-Shak V and Sokolova A 2003 Alteration of basalts from the Kerguelen Plateau; Proc. Ocean Drill Data Rep. 183 1-40.

Le Maitre R W, Streckeisen A, Zanettin B, Le Bas M J, Bonin B and Bateman P 2002 Igneous rocks: A classification and glossary of terms: Recommendations of the International Union of Geological Sciences Subcommission on the Systematics of Igneous Rocks; Cambridge University Press, 252p.

Leterrier J, Maury R C, Thonon P, Girard D and Marehal M 1982 Clinopyroxene composition as a method of identification of the magmatic affinities of paleo-volcanic series; Earth Planet Sci. Lett. 59 139-154.

Luhr J F 1997 Extensional tectonics and the diverse primitive volcanic rocks in the western Mexican volcanic Belt; Can. Mineral. 35 473-500.

Mazumder S K 1976 A summary of the Precambrian geology of the Khasi Hills, Meghalaya; Geol. Surv. India Misc. Publ. 23 311-324.

Mazumder S K 1986 The Precambrian framework of part of the Khasi Hills, Meghalaya; Rec. Geol. Surv. India 117(2) 1-59.

Mitra S, Priestley K and Bhattacharyya A K 2005 Crustal structure and earthquake focal depths beneath northeastern India and southern Tibet; Geophys. J. Inter. 160 $227-248$.
Mahoney J J, Graham D W, Christie D M, Johnson K T M, Hall L S and Vonderhaar D L 2002 Between a hotspot and a cold spot: Isotopic variation in the Southeast Indian Ridge asthenosphere, $86^{\circ}-118^{\circ} \mathrm{E} ;$ J. Petrol. 43 1155-1176.

Morimoto N, Fabries J, Ferguson A K, Ginzburg I V, Ross M, Seifert F A, Zussman J, Aoki K and Gottardi G 1988 Nomenclature of pyroxenes; Am. Mineral. 73 1123-1133.

Neal C R, Mahoney J J and Chazey III W J 2002 Mantle sources and the highly variable role of continental lithosphere in basalt petrogenesis of the Kerguelen Plateau and Broken Ridge LIP: Results from ODP leg 183; J. Petrol. 43 1177-1205.

Nagao K, Nishido H and Itaya T et al. 1984 An age determination by $\mathrm{K}-\mathrm{Ar}$ method; Bull. Hiruzen Research Institute, Okayama College of Science 9 19-38 (in Japanese with English abstract).

Oldham R D 1899 Report of the Great Earthquake of 12th June, 1897; Geol. Surv. India Memoir 46 257-276.

Palmer R W 1923 Geology of part of the Khasi and Jaintia Hills, Assam; Rec. Geol. Surv. India 55 143-168.

Rajasekhar R P and Mishra D C 2008 Crustal structure of Bengal Basin and Shillong Plateau: Extension of Eastern Ghat and Satpura mobile belts to Himalyan fronts and seismotectonics; Gondwana Res., doi: 10.1016/j.gr.2007.10.009.

Rajendran C P, Rajendran K, Daurah B P and Earnes A 2004 Interpreting the style of faulting and paleoseismicity associated with the Shillong, northeast India, earthquake: Implication for regional tectonism; Tectonics $\mathbf{2 3}$ TC4009, doi: 10.1029/2003TC001605.

Rao J M 2002 Petrology and geochemistry of dolerite dykes, West Garo Hills, Meghalaya: A preliminary study; Gondwana Res. 5(4) 884-888.

Rao J M, Rao G V S P and Sarma K P 2009 Precambrian mafic magmatism of Shillong Plateau, Meghalaya and their evolutionary history; J. Geol. Soc. India 73 $143-152$.

Ray J S and Pande K $2001{ }^{40} \mathrm{Ar} /{ }^{39}$ Ar age of carbonatitealkaline magmatism in Sung Valley, Meghalaya, India; Proc. Indian Acad. Sci.(Earth Planet. Sci.) 110 185-190.

Ray J S, Ramesh R and Pande K 1999 Carbon isotopes in Kerguelen plume-derived carbonatites: Evidence for recycled inorganic carbon; Earth Planet Sci. Lett. 170 205-214.

Ray J S, Pattanayak S K and Pande K 2005 Rapid emplacement of the Kerguelen Plume related Sylhet Traps, eastern India: Evidence from ${ }^{40} \mathrm{Ar}-{ }^{39} \mathrm{Ar}$ geochronology; Geophys. Res. Lett. 32 1-4.

Rickers K, Mezger K and Raith M M 2001 Evolution of the continental crust in the Proterozoic Eastern Ghats Belt, India and new constraints for Rodinia reconstruction: Implications from $\mathrm{Sm}-\mathrm{Nd}, \mathrm{Rb}-\mathrm{Sr}$ and $\mathrm{Pb}-\mathrm{Pb}$ isotopes; Precamb. Res. 112 183-210.

Saha A, Ganguly S, Ray J and Chaterjee N 2010 Evaluation of phase chemistry and petrochemical aspects of Samchampi-Samteran differentiated alkaline complex of Mikir Hills, northeastern India; J. Earth Syst. Sci. 119 675-699.

Saunders A D, Norry M J and Tarney J 1988 Origin of MORB and chemically depleted mantle reservoirs: Trace element constraints; J. Petrol. (Special Lithosphere issue), pp. 415-445.

Schellart W and Nieuwlan D A 2003 3D evolution of a pop-up structure above a double basement strike-slip fault: Some insights from analogue modeling; Geol. Soc. London, doi: 10.1144/GSL.SP.2003.212.01.11.

Shinjo R, Woodhead J D and Hergt J M 2000 Geochemical variation within the northern Ryukyu Arc: Magma 
source compositions and geodynamic implications; Contrib. Mineral. Petrol. $140263-282$.

Srinivasan V 2005 The Dauki Fault in northeast India through remote sensing; J. Geol. Soc. India 66 413-426.

Srivastava R K, Heaman L M, Sinh A K and Shihua S 2005 Emplacement age and isotope geochemistry of Sung Valley alkaline-carbonatite complex, Shillong Plateau, northeastern India: Implications for primary carbonate melt and genesis of the associated silicate rocks; Lithos $8133-54$.

Srivastava R K and Sinha A K 2004 The early Cretaceous Sung Valley ultramafic-alkaline-carbonatite complex, Shillong Plateau, northeastern India: Petrological and genetic significance; Mineral. Petrol. 80 241-263.

Srivastava R K and Sinha A K 2007 Nd and Sr isotope systematics and geochemistry of plume related early Cretaceous alkaline-mafic-ultramafic igneous complex from Jasra, Shillong Plateau, northeastern India; Geol. Soc. Am. Spec. Paper 430 815-830.

Steiger R H and Jager E 1977 Subcommission on geochronology: On the use of decay constants in geo- and cosmochronology; Earth Planet. Sci. Lett. 36 359-362.

Storey M, Kent R W, Saunders A D, Herg J, Salters V J M, Whitechurch H, Sevigny J H, Thirlwal M F, Leat P, Ghose N C and Gifford M 1992 Lower Cretaceous volcanic rocks on continental margins and their relationship to the Kerguelen Plateaus; In: Proceedings of the Ocean Drilling Program (eds) Wise S W and Schlich R, Scientific Results, College Station, TX, 120 33-53.

Sun S-S and McDonoug W F 1989 Chemical and isotopic systematics of oceanic basalts: Implications for mantle composition and processes; Geol. Soc. London, Spec. Publ. 42 313-345.

Talukdar S C 1966 Rhyolite and alkali basalt from the Sylhet Traps, Khasi Hills, Assam; Curr. Sci. 9 238-239.

Talukdar S C and Murthy M V N 1971 The Sylhet Traps, their tectonic history, and their bearing on problems of Indian flood basalt provinces; Bull. Volcanol. 35 602-618.

Veena K, Pandey B K, Krishnamurthy P and Gupta J $\mathrm{N} 1998 \mathrm{~Pb}, \mathrm{Sr}$ and Nd isotopic systematics of the carbonatites of Sung Valley, Meghalaya, northeast India:
Implications for contemporary plume-related mantle source characteristics; J. Petrol. 39 1875-1884.

Velasco-Tapia F and Verma S P 2001 First partial melting inversion model for a rift-related origin of Sierra de Chichinautzin volcanic field, central Mexican volcanic belt; Int. Geol. Rev. 43 788-817.

Verma R K and Mukhopadhyay M 1977 An analysis of the gravity field in northeastern India; Tectonophys. 42 283-317.

Verma S P, Torres-Alvarado I S and Sotelo-Rodríguez Z T 2002 SINCLAS: Standard igneous norm and volcanic rock classification system; Comput. Geosci. 28 $711-715$.

Vitrac A M, Albarede F and Allegre C J 1981 Lead isotope compositions of Hercynian granitic K-felspars constrain continental genesis; Nature 291 460-464.

Wang Y J, Liao C L, Fan W M and Peng T P 2004 Early Mesozoic OIB-type alkaline basalt in central Jiangxi Province and its tectonic implications; Geochim. 33 109-117.

Weaver B L 1991 The origin of ocean island end-member compositions: Trace element and isotopic constraints; Earth Planet Sci. Lett. 104 381-397.

Weis D, Ingle S P, Damasceno D, Frey F A, Nicolaysen K $\mathrm{P}$ and Barling J 2001 Origin of the continental components in Indian Ocean basalts: Evidence from Elan Bank (Kerguelen Plateau, ODP LEG 183, Site 1173 ); Geol. 29 147-150.

White W M and Patchett P J 1984 Hf-Nd-Sr isotopes and incompatible element abundances in island arcs: Implications for magma origins and crust-mantle evolution; Earth Planet Sci. Lett. 67 167-185.

Yin A, Dubey C S, Webb A A G, Kelty T K, Grove M, Gehrels G E and Burgess W P 2010 Geologic correlation of the Himalayan orogen and Indian craton: Part 1. Structural geology, U-Pb zircon geochronology, and tectonic evolution of the Shillong Plateau and its neighboring regions in NE India; Geol. Soc. Am. Bull. 122 336-359.

Zindler A and Hart S R 1986 Chemical geodynamics; Ann. Rev. Earth Planet. Sci. 14 493-571. 